\title{
10. \\ FRANCUSKA KNJIŽEVNOST \\ U PRIJEVODIMA PRIPADNIKA \\ SPLITSKOG KULTURNOG KRUGA
}

\section{Sanja Šoštarić}

UDK: 821.133 .1 (=163.42):316.74

Izvorni znanstveni članak

Sažetak: U uvodnom dijelu članka govori se o prijevodu kao elementu interkulturne komunikacije čiju su važnost često isticali francuski i hrvatski komparatisti (Van Tieghem, Guyard, Pichois, Rousseau, Chevrel, Masson, Hergešić) i sociolozi književnosti (Bourdieu, Sapiro, Heilbron). U nastavku se daje pregled prevoditeljskog rada pripadnika splitskog kulturnog kruga (Milan Begović, Vladimir Nazor, Tin Ujević, Verka Škurla-Ilijić, Ante Cettineo, Božena Begović, Frano Alfirević, Vinko Tecilazić, Bogdan Radica, Jerka Belan, Vojmil Rabadan, Ante Jurević i Vladan Desnica) i upozorava na njihovu važnu ulogu u posredovanju između francuske i hrvatske kulture te u povećanju simboličkog kapitala francuske književnosti u Hrvatskoj. Završni dio posvećen je trima hrvatskim prijevodima Gideovog putopisa Retour de l'U. R. S. S. (1936.), a naglasak je stavljen na Desničin prijevod toga djela, objavljen 1952. godine.

Ključne riječi: književno prevođenje, interkulturna komunikacija, komparativna književnost, splitski prevoditelji, francuska književnost, André Gide, Vladan Desnica

Prijevodi predstavljaju značajan element interkulturne komunikacije i važnu građu u književnoznanstvenim istraživanjima. Ne čudi, stoga, da je francuska komparatistika od svojih začetaka prevođenju i prijevodima posvećivala veliku pozornost. Tako je Van Tieghem, jedan od pionira komparativne književnosti, u svojoj knjizi La littérature comparée (1931.) istaknuo važnu ulogu prevoditelja kao neophodnih posrednika u književnoj razmjeni među narodima te ustvrdio da proučavanje prijevoda predstavlja preliminarni dio većine komparatističkih istraživanja. Po njegovom mišljenju, znanstveni rad treba se temeljiti na potpunom i točnom prijevodu nekog teksta, a često zahtijeva i dobro poznavanje prevoditelja (njegove biografije, književne karijere, društvenog statusa itd.). ${ }^{1}$

1 Paul Van Tieghem, „Les intermédiaires“, La littérature comparée, Paris 1931., 152-167. 
Van Tieghemovo su stajalište dijelili i drugi francuski komparatisti. Dok Marius-François Guyard ističe da su prijevodi „najrašireniji način upoznavanja stranih djela“2 te napominje da se u djelima posvećenim fortuni (recepciji) stranih pisaca redovno proučavaju i njihovi prevoditelji, ${ }^{3}$ posebice ako je riječ o jakim osobnostima ili prevoditeljima koji se hvataju u koštac sa značajnim djelima, ${ }^{4}$ Claude Pichois i André-Michel Rousseau prijevode vide kao „najlakše i najčešće sredstvo za upoznavanje remek-djela svjetske književnosti“, a proučavanje prijevoda „ponajprije [kao] stvar povijesti one književnosti u kojoj je prijevod nastao", 6 odnosno primateljske književnosti. Pichois i Rousseau ističu da istraživač mora proučiti prevoditelja, njegov rad te sociološke i komercijalne čimbenike koji su utjecali na izbor teksta za prijevod. Jednako tako, navedena dvojica komparatista naglašavaju nužnost izrade bibliografije koja bi sadržavala detaljne podatke (datum, mjesto i način publikacije, naklada, prodaja i cijena, broj i sastav čitatelja, ocjena tehničke vrijednosti prijevoda ili prevoditelja) o svim prijevodima na francuski jezik.

Početkom 21. stoljeća, Pichoisovu i Rousseauovu ideju realizirali su komparatisti Yves Chevrel i Jean-Yves Masson. Polazeći od stajališta da svi prijevodi čine sastavni dio nacionalne jezične i kulturne baštine što ih je tradicionalna povijest književnosti zanemarivala dajući prednost originalnim djelima, Chevrel i Masson pokrenuli su projekt Histoire des traductions en langue française (HTLF), čiji je cilj proučiti povijest prijevoda raznih tekstova (književnih, filozofskih, vjerskih, znanstvenih itd.) na francuski jezik u razdoblju od srednjeg vijeka do kraja 20. stoljeća. ${ }^{7}$

Francuska komparatistika snažno je utjecala na mnoge europske komparatiste, pa tako i na Ivu Hergešića, romanista i osnivača zagrebačke Katedre za komparativnu književnost. Hergešić je u program Katedre uvrstio i predavanja o književnim posrednicima (prijevodima) te o stranim pobudama u hrvatskoj književnosti i francusko-hrvatskim književnim dodirima. Prevođenju je pristupio kao komparatist (isticao je znanje stranih jezika kao važnu kompetenciju komparatista), prevoditelj (dosta je prevodio, u prvom redu s francuskog, španjolskog i njemačkog jezika) i traduktolog (1934. napisao je kraći tekst o prevođenju). $\mathrm{U}$ traduktološkom spisu naslovljenom „O prijevodima i prevođenju“ Hergešić preuzima većinu Van Tieghemovih postavki, ali iznosi i neka vlastita razmišljanja: ističe da mali narodi moraju učiti strane jezike, odnos pisca i prevoditelja uspoređuje s brakom, tvrdi da književna djela treba prevoditi književnik, vičan baratati književnim instrumentima itd. ${ }^{8}$

Važna uloga prijevoda u interkulturnoj razmjeni i u književnoznanstvenom istraživanju - na kojoj inzistiraju komparatisti - za sobom povlači i određene opasnosti na koje je upozorio francuski sociolog Pierre Bourdieu, autor tzv. teorije književnog polja. Bourdieu, naime, upozorava da djela (književna, filozofska i dr.) prilikom izmještanja iz jednog polja

\footnotetext{
Marius-François GuYard, La littérature comparée, Paris 1965., 16.

Isto, 28.

Isto, 33.

Claude Pichois - André-Michel Rousseau, Komparativna književnost, Zagreb 1973., 64.

Isto, 65.

Jean-Yves Masson - Yves Chevrel, „Histoire des traductions en langue française“ (http://www.crlc.paris-sorbonne. fr/FR/Page_axe_recherche.php?P1=9).

8 Ivo Hergešić, „O prijevodima i prevođenju“, Komparativna književnost, Zagreb 2005., 109-120.
} 
$\mathrm{u}$ drugo, odnosno iz nacionalnog u internacionalno polje, sa sobom ne nose svoj originalan kontekst, što može dovesti do nesporazuma. ${ }^{9}$ Kako upozoravaju sociolozi Johan Heilbron i Gisèle Sapiro, polje u koje se (prevedeno) djelo prenosi, određeno je cijelim nizom specifičnih čimbenika i instancija (kontrola tiska, izdavačka struktura, specijalizirane biblioteke ili kolekcije, izdavačka politika pojedinih izdavačkih kuća, časopisi i novine, razni oblici konsekracije itd.) koji utječu na interpretaciju i recepciju. Po njihovom mišljenju, prijevod nije samo instrument posredovanja i razmjene, nego može imati i političku i ekonomsku funkciju te biti oblik legitimacije i konsekracije kako autora djela tako i njegovog prevoditelja. ${ }^{10}$

\section{II.}

Procesu konsekracije pojedinih francuskih pisaca, kao i francuske književnosti u cjelini, značajan su doprinos dali pripadnici splitskog kulturnog kruga: Milan Begović, Vladimir Nazor, Tin Ujević, Verka Škurla-Ilijić, Ante Cettineo, Božena Begović, Frano Alfirević, Vinko Tecilazić, Bogdan Radica, Jerka Belan, Vojmil Rabadan, Ante Jurević i Vladan Desnica. Njihovi prijevodi predstavljaju potvrdu kontinuiranog zanimanja za francusku književnost koje se kod hrvatskih čitatelja može pratiti od druge polovice 19. stoljeća. Među instancijama koje su odigrale važnu ulogu u posredovanju između francuske i hrvatske kulture posebno treba istaknuti školstvo (1876. francuski je jezik postao obavezni predmet u gimnazijama, a 1883. organizirana je nastava francuskog jezika na Filozofskom fakultetu u Zagrebu) i časopise, u prvom redu Vienac, središnji književni časopis druge polovice 19. stoljeća, a potom i brojne časopise hrvatske moderne koji izlaze na prijelazu iz 19. u 20. stoljeće. ${ }^{11}$ Po svjedočenju Nikole Andrića, utemeljitelja i urednika Zabavne biblioteke, zanimanje za francusku književnost i učenje francuskog jezika još je izraženije nakon Prvoga svjetskog rata. ${ }^{12} \mathrm{Ne}$ čudi, stoga, da se u Zabavnoj biblioteci - koja broji 600 svezaka - nalazi čak 116 francuskih naslova.

Među prevoditeljima u Andrićevoj biblioteci našli su se i neki pripadnici splitskog kulturnog kruga (Škurla-Ilijić, Radica, Nazor, Ujević, M. Begović, Rabadan). Većina ih je, međutim, svoje prijevode objavila u nekim drugim izdanjima (u prvom redu u knjigama, a dijelom i u časopisima). ${ }^{13}$ Iako su rođenjem ili određenim životnim okolnostima bili ve-

9 Pierre Bourdieu, „Les conditions sociales de la circulation internationale des idées“, Actes de la recherche en sciences sociales, 2002., br. 145, 3-8.

10 Johan Heilbron - Gisèle SApiro, „La traduction littéraire, un objet sociologique“, Actes de la recherche en sciences sociales, 2002., br. 144, 3-5.

11 U Viencu je od 1869. do 1900. g. objavljeno 215 djela u hrvatskom prijevodu, od čega 115 prijevoda s francuskog. Kad su u pitanju časopisi moderne, francuska je orijentacija bila posebno izražena među pripadnicima tzv. bečkozagrebačke grupe.

12 Andrić to objašnjava željom hrvatskih čitatelja da njemački tvrdi duh i način mišljenja zamijene vedrijim i jasnijim francuskim stajalištima. V. Nikola Andrić, „Našim čitaocima“, u: Paul Bourget, Druga ljubav, Zagreb 1919., 3-5.

13 U Jadranskoj straži postojala je rubrika Književni dio u kojoj se mogu naći pjesme i kraći prozni tekstovi domaćih i stranih pisaca (uključujući i francuske). Ovisno o godištima, navedena je rubrika sadržavala između 20 i 80 priloga, a među prevedenim francuskim autorima nalaze se: Hugo (1935., preveo Ivo Mirković), Supervielle (1936., preveo Ante Cettineo; 1941., prev. M. Č.), Dupouy (1937. i 1938., preveo dr. S. M., ilustrirao A. Maurović) i Daudet (1940., preveo R. B. Maldini). Za razliku od Jadranske straže, splitski književni časopisi (Renesansa, Suvremeni vidici, Korablja), pokrenuti 1920-ih, bili su vrlo kratkog vijeka. 
zani za Split, ${ }^{14}$ svoje su prijevode najčešće objavljivali kod zagrebačkih izdavača (Kuća dobre štampe, Zor, Matica hrvatska, Glas rada i dr.). ${ }^{15} \mathrm{O}$ važnoj ulozi pripadnika splitskog kulturnog kruga u posredovanju između francuske i hrvatske kulture svjedoče podaci o njihovoj bogatoj prevoditeljskoj djelatnosti, koja će biti predstavljena kroz niz kratkih prevoditeljskih portreta. ${ }^{16}$

Književnik Milan Begović (1876. - 1948.) uglavnom je prevodio za kazalište. Među njegovih četrdesetak prijevoda nalazi se i pet drama prevedenih s francuskog: Pelleas i Melisanda Mauricea Maeterlincka (1907.), Gola žena Henryja Bataillea (1911.), Slomljena krila Pierrea Wolfa (1921.), Kradljivka Paula Armonta i Marcela Gerbidona (1928.) i U svijetu dosade Édouarda Paillerona (1928.).

Vladimir Nazor (1876. - 1949.) prevođenjem se počeo baviti usporedo s pisanjem poezije. Iako je uglavnom prevodio $s$ talijanskog i njemačkog, preveo je i 44 pjesme francuskih pjesnika 19. stoljeća, a najveći broj njegovih prepjeva - njih 38 - objavljen je u Ježićevoj antologiji Francuska lirika (1941.). U navedenoj antologiji dominiraju Nazorovi prijevodi Hugoa (6 pjesama), Baudelairea (5 pjesama ${ }^{17}$ i Sullyja Prudhommea (3 pjesme), dok su ostali pjesnici zastupljeni $s$ jednom ili dvije pjesme. Osim toga, Nazor se zanimao i za teoriju prevođenja pa se kod njega može naći i poneko traduktološko razmišljanje.

Tin Ujević (1891. - 1955.) prevođenju se posvetio nakon što mu je 1945. zabranjeno javno djelovanje. S francuskog je prevodio poeziju Rimbauda (Sezona u paklu) i Verhaerena (Sunce u čovjeku, 1951.), a 1952. objavljeni su Baudelaireovi Cvjetovi zla, koje je preveo s Dunjom Robić (1922. - 1999.) i Splićaninom Antom Jurevićem (1913. - 1989.). ${ }^{18}$ U Ježićevoj je antologiji Ujević objavio jednu Mallarméovu i jednu Divoireovu pjesmu. Njegov je prevoditeljski opus vrlo raznolik pa obuhvaća i Albert-Jeanov „osrednji pustolovni roman “19 Zatočena ljubav (1932.) i romane iz Proustovog ciklusa $U$ traganju za izgubljenim vremenom (Jedna Swannova ljubav, 1953.; U sjeni procvalih djevojaka, 1955.; Vojvotkinja de Guermantes, 1955.; Combray, 1977.). Pored Prousta, Ujević je prevodio i druge klasike francuske proze: Zolu (Germinal, 1946.), Balzaca (Seljaci, 1947.; Slike iz seoskog života, 1960.), Stendhala (Talijanske kronike, 1948.; Opatica iz Castra, 1949.), Daudeta (Tartarinova trilogija, 1948.), Flauberta (Novembar, 1950.), Maupassanta (Jedan život, 1952.) i Sartrea (Mučnina, 1952.).

14 Kao što je u svom izlaganju na Desničinim susretima 2015. istaknula Iva Grgić Maroević, riječ je o autorima koji su rodom iz Splita ili onima koji su za Split vezani obrazovanjem, formiranjem, djelovanjem ili neočekivanim biografskim okolnostima.

15 Mnogi su umjetnici 1930-ih napuštali Split i odlazili u veća središta, najčešće u Zagreb i Beograd. V. Zdravka JeLAsKa Marijan, Grad i ljudi: Split 1918.-1941., Zagreb 2009., 459.

16 Podaci o prevoditeljskoj djelatnosti pripadnika splitskog kulturnog kruga prikupljeni su iz knjižničnih kataloga (Nacionalna i sveučilišna knjižnica, Knjižnice grada Zagreba, Knjižnica Filozofskog fakulteta u Zagrebu), referentne građe (Hrvatska enciklopedija, Proleksis enciklopedija, Hrvatski biografski leksikon, Bibliografija rasprava, članaka $i$ književnih radova, Katalog Zabavne biblioteke, Svjetska književnost u hrvatskim prijevodima), časopisa (Jadranska straža), antologija poezije i sabranih djela pojedinih hrvatskih pisaca.

17 O Nazorovim prijevodima Baudelaireove poezije v. Cvijeta PAvLović, „Nazorovi prijevodi Baudelairea“, Hrvatskofrancuske književne veze. 15 studija, Zagreb 2008., 145-155.

18 Manji broj prijevoda navedenih u ovom članku nastao je u koautorstvu, ali kako - s izuzetkom Jurevića - nije riječ splitskim koautorima, podaci o njima nisu navođeni.

19 Hergešić je taj prijevod ovako prokomentirao: „(...) ima i slučajeva, kad je prevodilac tako reći iznad samoga pisca: nije li tužno, da je osrednji pustolovni roman kao što je Zatočena ljubav Albert Jeana morao prevesti ovako velik pjesnik kao što je Tin Ujević.“ (I. Hergešrć, „O prijevodima i prevođenju“, 119.) 
Književnica i prevoditeljica Verka Škurla-Ilijić (1891. - 1971.) za Andrićevu je Zabavnu biblioteku prevela tri francuska sentimentalna romana: Magali (1922.), koji su pod pseudonimom Delly napisali Marie i Frédéric Petitjean de la Rosière, Utočište (1923.) Jacquesa Bascheta te Novi potop (1933.) Noëlle Roger.

Pjesnik Ante Cettineo (1898. - 1956.) prevodio je s portugalskog, španjolskog i francuskog jezika. U Jadranskoj straži objavio je prijevode osam brazilskih i portugalskih pjesama te pet pjesama francuskog pjesnika Julesa Superviellea (1936.). Prevodio je i brazilsku prozu.

Kći Milana Begovića, Božena Begović (1901. - 1966.), bila je glumica, književnica i prevoditeljica. Prevodila je književna djela - Saint-Exupéryja (Zemlja ljudi, Noćni let, 1944.), Balzaca (Mercadet, 1947.), Maupassanta (Yvette, 1952.; Ljubavni sastanak, 1978.), Édith Thomas (Eva i druge, 1955.) i Stendhala (Život Henrija Brularda, 1957.), ali i francusku memoarsku prozu, romansirane biografije te studije iz povijesti i povijesti umjetnosti.

Pisac i prevoditelj Frano Alfirević (1903. - 1956.) diplomirao je francuski jezik na Filozofskom fakultetu u Zagrebu i kao stipendist francuske vlade proveo devet mjeseci u Montpellieru. S francuskog je prevodio Anatolea Francea i Paula Valéryja. Zanimanje za život bretonskih ribara (napisao je raspravu koja je u Francuskoj objavljena i nagrađena) vjerojatno ga je potaknulo da 1952. prevede roman Pierrea Lotija Islandski ribar.

Vinko Tecilazić (1904. - 1989.) s francuskog je prevodio Duhamela (Ponoćna ispovijed, 1940.), Aragona (Baselska zvona, 1946.), Zolu (Slom, 1950.; Novac, 1952.), Guillouxa (Crna krv, 1951.), Barbussea (Oganj, 1952.), Dabita (Nenadana smrt, Pariska predgrada, 1952.), Balzaca (Veličina i pad Césara Birotteaua, 1953.; Banka Nucingen, 1953.; Slike iz pariskog života, 1960.; Slike iz privatnog života, 1960.), Vernea (Put na mjesec, 1953.), Nizana (Urota, 1956.), Vaillanda (325 000 franaka, 1957.) i Butora (Izmijenjena odluka, 1958.). Pored toga, Tecilazić je preveo i drugi dio Proustovog ciklusa $U$ traganju za izgubljenim vremenom (Sodoma i Gomora, 1958.; Zatočenica, 1963.; Bjegunica, 1965.; Pronadeno vrijeme, 1965.).

Navedenim podacima valja pridodati da je u već spomenutoj Zabavnoj biblioteci objavljen i roman Nerancula (1930.) Panaita Istratija, rumunjskog pisca francuskog jezičnog izričaja. ${ }^{20}$ Predgovorom ga je popratio Bogdan Radica (1904. - 1993.), splitski povjesničar, publicist, književnik i prevoditelj. U istoj se biblioteci Radica našao i u ulozi prevoditelja Unamunovih djela Magla i Tri uzorite novele (1929.), za koja je također napisao predgovor.

Prevoditeljica Jerka Belan (1906. - 1993.) prevodila je djela francuskih prozaika: Zole (Lurd, 1951.; Osvajanje Plassansa, 1955.), Dabita (Hotel Sjever, 1952.), Ayméa (Zelena kobila, 1958.) i Sartrea (Zid, 1956.; Intimnost, Soba, 1965.). U njezinom se prevoditeljskom opusu nalaze i djela dviju književnica - Françoise Sagan (Predaja, 1967.) i Raphaele Billetdoux (Osvrni se na lijepe stvari, 1980.) - te manje prevođenih pisaca - Casanove (Bijeg iz mletačke tamnice, 1953.), Jacquemarda (Mafija u Parizu, 1978.) i Falleta (Školjka Ljupka ili Glas oceana, 1982.).

Književnik, redatelj, dramaturg, teatrolog i prevoditelj Vojmil Rabadan (1909. - 1988.) doktorirao je 1957. na Filozofskom fakultetu u Zagrebu s temom iz francuske književnosti.

$\overline{20}$ U knjizi je kao prevoditelj naveden M. Mirč (Vel. Bečkerek). 
Prevodio je sa starogrčkog, latinskog, talijanskog, slovenskog i bugarskog jezika. S francuskog je preveo cjelokupni pjesnički opus Françoisa Villona (1978.), a svoj je prijevod (tiskan usporedo s originalnim tekstom) popratio brojnim komentarima i studijom o Villonu. ${ }^{21}$ Prevodio je i djela francuskih romanopisaca 19. i 20. stoljeća: Ghéona (Tri kralja, 1934.; Santaremski daci, 1935.), Bazina (Zemlja umire, 1935.) i Suea (Tajne grada Pariza, 1969.).

Kao što je vidljivo iz podataka o prevoditeljskoj djelatnosti pripadnika splitskog kulturnog kruga rođenih krajem 19. i početkom 20. stoljeća, ${ }^{22}$ njihov je opus bogat i žanrovski raznolik. Najčešće ipak prevode djela pisaca iz 19. i 20. stoljeća, u prvom redu prozu, potom poeziju i dramska djela. Iako je riječ o prevoditeljima koji uglavnom prevode s nekoliko stranih jezika, prevođenje nije njihova primarna djelatnost: među njima se nalaze klasici hrvatske književnosti, ugledni kazališni djelatnici, publicisti i dr.

\section{III.}

Neke osobitosti splitskih prevoditelja mogu se uočiti i kod Vladana Desnice, književnika, scenarista, kritičara i prevoditelja s nekoliko jezika. Tijekom 1950-ih i 1960-ih Desnica je objavio veći broj prijevoda s francuskog, talijanskog i ruskog jezika. ${ }^{23} \mathrm{Kad}$ je u pitanju francuski jezik, Desničin prevoditeljski opus obuhvaća prozna djela iz 20. stoljeća: sedam noveleta Jeana Paulhana (1954.), dvije zbirke pripovijetki Marcela Ayméa (Priče mačke na grani, 1963.; Druge priče mačke na grani, 1965.) te dva putopisa Andréa Gidea (Povratak iz SSSR i Dopune mom Povratku iz SSSR, 1952.). Najzanimljivijom se građom za ovaj rad pokazao prijevod Gideovih putopisa koji su u Francuskoj izazvali burne reakcije i polemike, a u Hrvatskoj doživjeli tri različita izdanja.

Gideove simpatije prema Staljinu i sovjetskom komunizmu francuski su čitatelji uočili 1932., kada je časopis Nouvelle Revue française počeo objavljivati ulomke iz piščevog dnevnika. ${ }^{24}$ Četiri godine poslije, u lipnju 1936., Gide je dobio poziv da posjeti Moskvu. Tijekom svog desetotjednog boravka u Sovjetskom Savezu - koji su domaćini pomno isplanirali - Gide se susreće s oduševljenim radnicima, posjećuje parkove kulture, razgledava tvornice, ogledne radničke gradove i odmarališta, ali ubrzo uočava i ono što mu sovjetski vodiči nisu željeli pokazati: materijalnu bijedu radništva, društvenu nejednakost, višak birokracije, manjak kritičkog duha, slobode i individualnosti, kult ličnosti, kompleks superiornosti prema inozemstvu itd. Kao deklariranom homoseksualcu, posebno mu je zasmetao zakon koji

21 O Rabadanovom prijevodu Villona v. Nenad Ivić, „Rabadanova 'Summula villoniana', Napulj i druga imaginarna mjesta, Zagreb 2009., 114-122.

22 Budući da su splitski prevoditelji druge generacije (Selem, D. Bradičić, Tomasović, Mrkonjić, Klarić, Telećan, Budor i Maroević) rođeni između 1936. i 1941. godine, njihovi prijevodi nisu obuhvaćeni ovim radom.

23 Dušan Marinković, „Biografija Vladana Desnice“, Hotimično iskustvo: diskurzivna proza Vladana Desnice. Knjiga druga (prir. Dušan Marinković), Zagreb 2006., 240.

24 Tom je prigodom romanopisac François Mauriac s čuđenjem primijetio da Gide, koji je mlade podučavao da je svako ljudsko biće jedinstveno i nezamjenjivo, „sada priželjkuje trijumf boljševičkog termitnjaka u kojem će svatko biti zamjenjiv“. V. Claude Martin, Gide, Paris 1963., 166. 


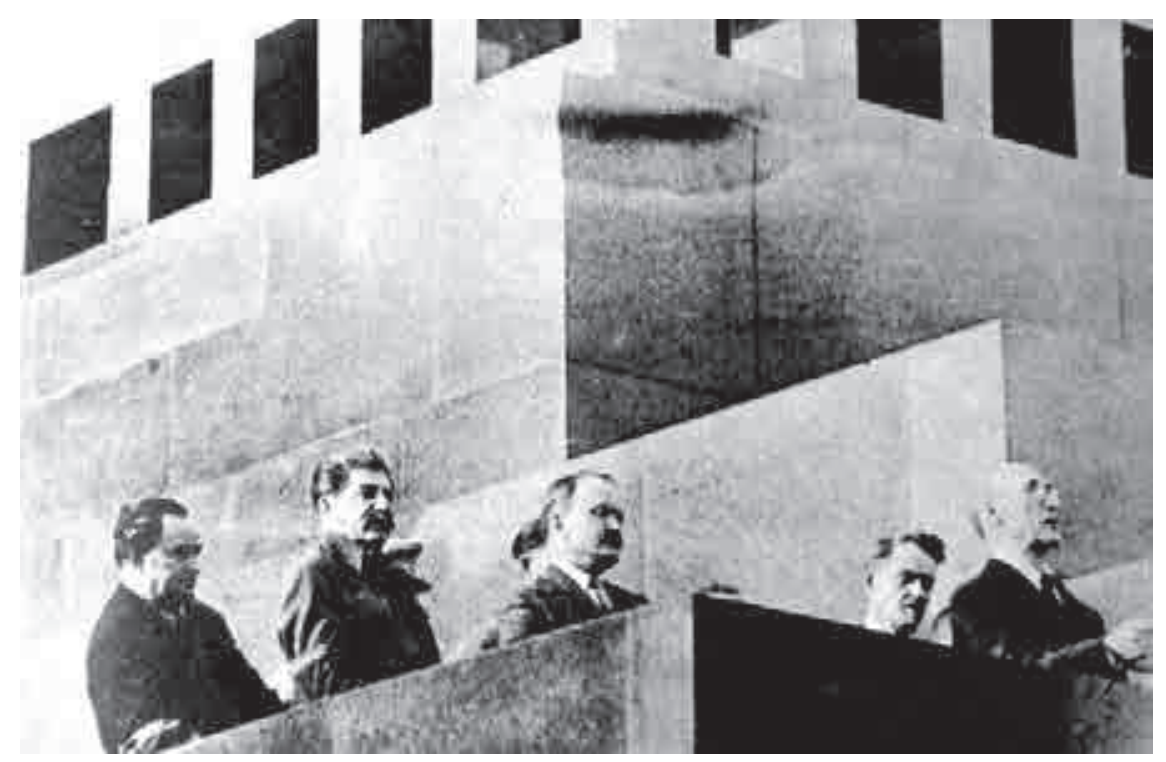

Sl. 1. André Gide (prvi zdesna) drži govor na Lenjinovom mauzoleju u povodu smrti Maksima Gorkog 1936. godine

homoseksualce tretira kao kontrarevolucionare i „osuđuje na deportaciju od pet godina, $s$ mogućnošću produženja kazni, ako se za vrijeme progonstva ne poprave“. ${ }^{25}$ Svoja zapažanja i dojmove Gide je iznio u putopisu Retour de l'U. R. S. S. (1936.), koji je odmah po objavljivanju izazvao veliku polemiku: žestoko su ga napali članovi i simpatizeri Komunističke partije Francuske, među kojima su se nalazili i mnogi književnici (primjerice, Rolland, Nizan, Aragon). Napadi su rezultirali dobrom prodajom putopisa (u godinu dana prodan je u više od sto tisuća primjeraka) i tiskanjem njegovog nastavka: u lipnju 1937. Gide objavljuje kraće djelo Retouches à mon Retour de l'U. R. S. S. u kojem se, duboko razočaran, definitivno udaljava od sovjetskog komunizma.

Upravo u to vrijeme (između 1935. i 1938. godine) sa Gideom se u Parizu nekoliko puta susreo Bogdan Radica, istaknuti i svestrani pripadnik splitskog kulturnog kruga. Radica Gidea naziva „pretečom personalizma“. Njegovo djelovanje definira kao „posljednju i konačnu obranu Zapada u namjeri da se protiv barbarskih i poganskih veriga totalitarizma - ma kakav on bio - postavi kategorički imperativ neovisnosti i slobode čovjekove ličnosti“" ${ }^{26}$ a njegov putopis drži značajnijim za Pariz i Zapad nego za Rusiju. Kako je Gideov putopis kod nas doživio čak tri prijevoda, nameće se zaključak da je riječ o djelu koje je bilo značajno i za Hrvatsku.

Prvi je hrvatski prijevod Gideovog putopisa tiskan 1937., samo godinu dana nakon objavljivanja francuskog izdanja. Prevoditeljevo ime nije poznato, a djelo je objavila Knjižara Ćelap, izdavačka kuća koju je 1918. osnovao Vinkovčanin Đorđe Ćelap. Godine 1926.

25 André GIDE, Povratak iz SSSR; Dopune mom Povratku iz SSSR, Zagreb 1952., 26. Preveo s francuskog Vladan Desnica.

26 Bogdan RadicA, „André Gide: između vječnog odlaska i povratka“, Agonija Europe. Razgovori i susreti, Zagreb 2006., 128. 


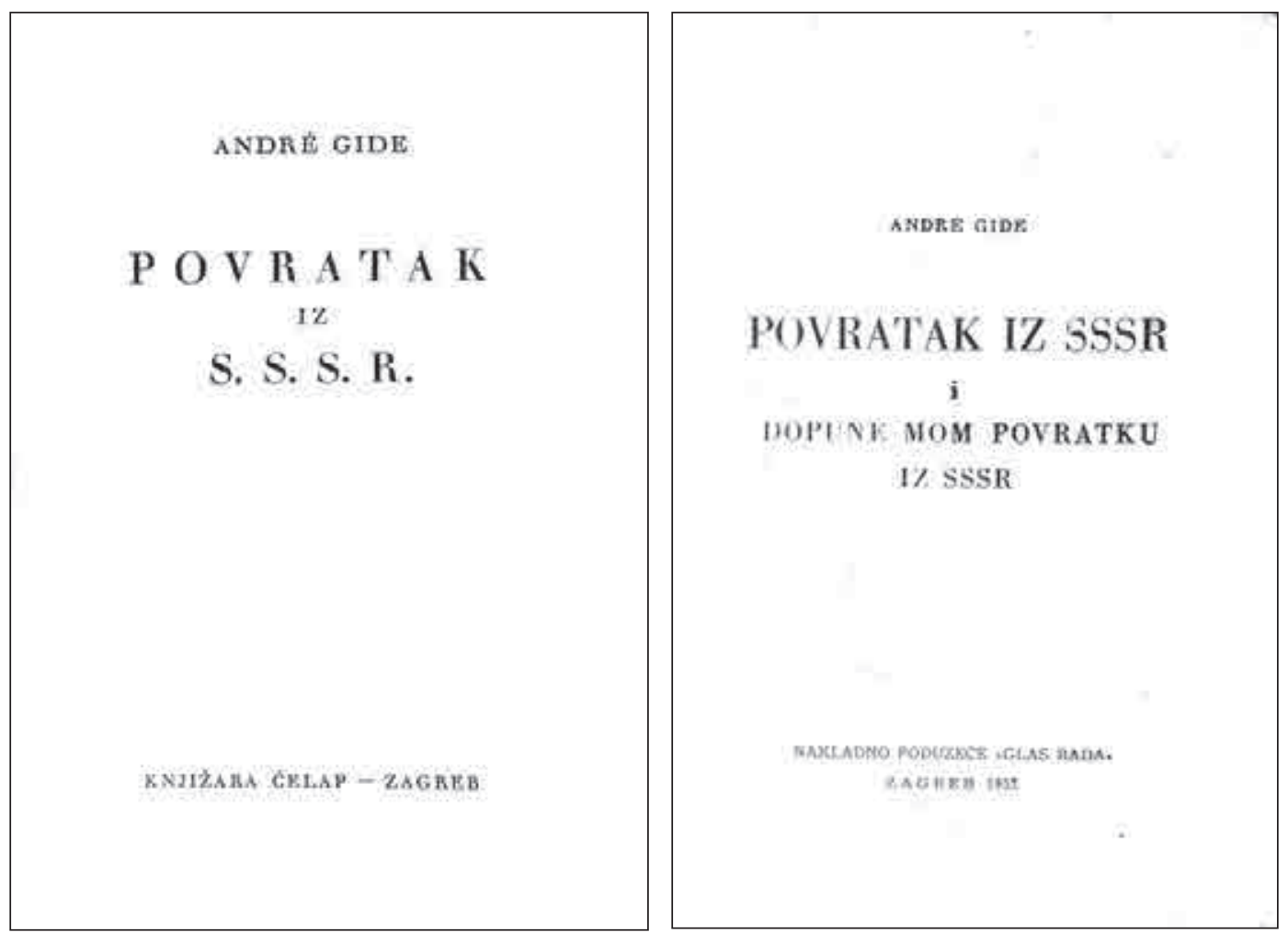

Sl. 2. i sl. 3. Povratak iz SSSR André Gidea u dva izdanja i dva prijevoda (Ćelap 1937. i Glas rada 1952.)

Ćelap u Zagrebu otvara vlastitu knjižaru koja će nakon Drugoga svjetskog rata biti konfiscirana i pripojena poduzeću Mladost. Tijekom 27 godina rada (1918. - 1945.) Knjižara Ćelap objavila je 40-ak naslova, od čega oko polovicu čine književna djela. Francuska je književnost zastupljena sa svega tri djela: pored Gideovog putopisa, objavljeni su Racineov Britanik (1940.) i Molièreov Tartuffe (1938.). Valja napomenuti da se Ćelap tijekom gimnazijskih dana upoznao s Krležom i prva knjiga koju je tiskao u svojoj nakladi bila je Hrvatska rapsodija (1918.), uz koju su u istom svesku objavljeni i Kraljevo i Cristoval Colon. Ćelapovo zanimanje za Gideov Povratak vjerojatno valja povezati s njegovim prijateljstvom s Krležom, koji je također putovao u Sovjetski Savez te objavio putopis Izlet u Rusiju (1926.). ${ }^{27}$ Sudi li se po člancima u onovremenoj jugoslavenskoj periodici, objavljivanje Gideovog putopisa predstavljalo je dobar poslovni potez: u razdoblju između 1936. i 1939. objavljeno je, naime, četrdesetak članaka o Gideu, od čega su čak 33 povezana s njegovim putopisima po Sovjetskom Savezu (mahom se radi o prikazima Povratka i njegovog nastavka te manjim dijelom o člancima posvećenim Gideovim političkim stajalištima). ${ }^{28}$

\footnotetext{
${ }^{27}$ O Krležinom putopisu v. Aleksandar FlaKer, Riječi slika, grad, rat. Hrvatske intermedijalne studije, Zagreb 2009. O Gideovom i Krležinom putopisu v. Maja ZoricA, „Les pérégrinations de Gide et de Krleža: les Russies ou les lignes de fuite du référent (Retour de l'U.R.S.S., Retouches à mon 'Retour de l'U.R.S.S.' et L'excursion en Russie)“, Les Cahiers ERTA, 2013., br. 3, 143-159.

28 V. Bibliografija rasprava, članaka i književnih radova, sv. I. 3: Nauka o književnosti. Historija stranih književnosti (ur. Ivo Horvat), Zagreb 1959.
} 
Petnaest godina nakon Ćelapovog izdanja, Nakladno poduzeće Glas rada objavilo je Povratak iz SSSR i Dopune mom Povratku iz SSSR (1952.) u prijevodu Vladana Desnice. Ovo izdanje Gideovih putopisa objavljeno je kratko nakon piščeve smrti (1951.) ${ }^{29}$ i četiri godine nakon što mu je dodijeljena Nobelova nagrada za književnost (1947.). Čini se, međutim, da odluku o objavljivanju novog prijevoda u prvom redu treba povezati s društveno-političkom situacijom: Gideov je putopis, naime, doživio drugo hrvatsko izdanje u razdoblju kada su zbog Rezolucije Informbiroa odnosi između Sovjetskog Saveza i Jugoslavije bili vrlo zategnuti i kada se Jugoslavija okretala Zapadu kako u ekonomskom tako i u kulturnom smislu. Analiza jugoslavenske izdavačke produkcije 1950-ih pokazuje da se u to vrijeme intenzivno prevode djela pisaca tzv. zapadnog književnog kruga. ${ }^{30}$ Gide je, dakle, hrvatskim izdavačima i čitateljima bio zanimljiv i kao francuski pisac i kao autor djela s izrazitim antisovjetskim tonom. I predgovor novom izdanju Gideovog putopisa potvrđuje da za njegovo ponovno objavljivanje postoje politički razlozi. Desničin je prijevod, naime, predgovorom popratio Rudi Supek, koji se tijekom jugoslavensko-sovjetskog sukoba odbio ograditi od Tita. ${ }^{31}$ Supek Gideova politička stajališta stavlja u kontekst različitih pristupa „građanskih intelektualaca“ komunizmu. Na pitanje „kakav stav treba da zauzmemo prema ovome Gidovom svjedočanstvu“, ${ }^{32}$ Supek iznosi mišljenje da se „prema Gidovoj kritici SSSR možemo odnositi s izvjesnom pažnjom, ma kako ona bila zadojena natruhama buržoaskog individualizma, jer se njegov antisovjetizam, pa i antimarksizam ne može ocijeniti kao antikomunizam u posljednjim konsekvencama“. ${ }^{33}$ Riječ je, dakle, o djelu koje osuđuje jedan oblik komunizma - sovjetski, odnosno Staljinov - a ne komunizam u cjelini.

Gideovi putopisi u skladu su s izdavačkom politikom Glasa rada, malog izdavača koji je tijekom svog kratkog postojanja (1946. - 1953.) objavio stotinjak naslova: uglavnom je riječ o književnim djelima, ali brojna su i djela o društveno-političkim temama (o revoluciji i marksizmu, komunizmu i socijalizmu, političkim progonima u Mađarskoj, Informbirou, samoupravljanju, odnosu Crkve i države itd.).

Zanimljivo je da je u razdoblju između dva izdanja Povratka (od 1937. do 1952.) na hrvatski prevedeno samo jedno Gideovo djelo: 1939. godine tiskan je roman Krivotvoritelji u prijevodu Antuna Bonifačića. Potom su 1952. i 1953. objavljena čak četiri Gideova djela: tri politički obojena putopisa (Povratak iz SSSR, Dopune mom Povratku iz SSSR, Put u

$\overline{29}$ Zanimljivo je da Desnica 1953. piše ironično intoniran članak o prolaznosti pojedinih pisaca „po Jevropama“ u kojem iznosi stajalište „obaviještenih ljudi“ da je Gide „van mode“ i da je zanimanje za njega tek „slabo i zakratko“ oživjela njegova smrt. V. Vladan Desnica, „Lađe i galebovi“, Hotimično iskustvo. Knjiga prva (prir. Dušan Marinković), Zagreb 2005., 103-105.

30 Prema podacima prikupljenim za drugi dio ovoga rada, u razdoblju između 1950. i 1960. splitski prevoditelji objavili su prijevode 30 francuskih proznih djela (romani, dulje novele, putopisi) i dviju zbirki pjesama.

31 Od Supeka se, kao člana KP Francuske, 1948. tražilo da se izjasni protiv Tita i jugoslavenskog komunizma, što je on odbio te se vratio u Zagreb. Odluku o povratku Supek je donio u trenutku kad se u Jugoslaviji preispitivao rad jugoslavenskog logoraškog komiteta koji je za vrijeme Drugog svjetskog rata djelovao u Buchenwaldu. Supek je u tom koncentracijskom logoru proveo 15 mjeseci i za to je vrijeme bio jedna od čelnih osoba zajednice jugoslavenskih logoraša. V. Marijan Bosnar „Rudi Supek i nacistički koncentracijski logor Buchenwald kroz arhivsko gradivo Hrvatskog državnog arhiva“, Arhivski vjesnik, 54/2011., 153-178.

32 Rudi Supek, „O A. Gidu i 'Povratku'“, u: A. GIDE, Povratak iz SSSR i Dopune mom Povratku iz SSSR, XXI.

33 Isto, XXIII. 
Kongo) i jedan roman (Krivotvoritelji novca). ${ }^{34}$ Nepravedno zapostavljenom Gideu hrvatski su se izdavači vratili tek 1974. (Uska vrata, preveli I. Klarić i dr.), odnosno 1980., kada je izdavačka kuća Otokar Keršovani objavila njegova odabrana djela, među kojima su se našli i Povratak iz SSSR-a i Ispravci mog Povratka iz SSSR-a u prijevodu Darka Gašparovića. Čini se da se izdavanjem osam svezaka Gideovih odabranih djela želio ispraviti propust hrvatskih izdavača ${ }^{35}$ očito ne previše zainteresiranih za autora koji je u Francuskoj već u razdoblju između dva rata bio etabliran pisac i postao dijelom francuskog književnog kanona. Tako je 1980-ih Gide napokon konsakriran i u polju hrvatske književnosti.

$\mathrm{Na}$ kraju valja još jednom istaknuti da tri prijevoda istoga djela predstavljaju rijetku pojavu na malom izdavačkom i čitateljskom tržištu kao što je hrvatsko. Istraživanje je, stoga, u skladu s Bourdieuovim postavkama o književnom polju, analizom izvantekstualnih elemenata nastojalo rasvijetliti pobude za objavljivanje triju izdanja Gideovog Povratka: dok se tiskanje prvog izdanja može objasniti izdavačevim osobnim (poznanstvo s Krležom) i komercijalnim motivima (dobar uspjeh knjige u Francuskoj), za drugo su izdanje bili presudne političke okolnosti (sukob između Jugoslavije i Sovjetskog Saveza), a za treće u prvom redu kulturni razlozi (nedostatan broj prijevoda Gideovih djela na hrvatski jezik).

Bilo bi, dakako, zanimljivo napraviti i komparativnu traduktološku analizu tih triju prijevoda, ali budući da bi ona izlazila iz okvira teme ovoga članka, valja se ograničiti na kraću analizu Desničinog prijevoda. Riječ je o radu koji u potpunosti zadovoljava uvjete koje navode komparatisti: prijevod je točan i potpun; prevedeno je važno djelo francuske književnosti; prevoditelj je jaka osobnost, a ujedno je i književnik koji vješto barata jezikom. Desničin je prijevod leksički, sintaktički i stilski gledano na visokoj razini i potvrđuje često ponavljanu traduktološku definiciju da dobar prijevod podrazumijeva spajanje čitanja i ponovnog pisanja, odnosno interpretacije i kreativnosti.

Kad su u pitanju Desničini prijevodi, jednako kao i prijevodi ostalih pripadnika splitskog kulturnog kruga, teško je ustanoviti je li riječ o djelima koja su birali prevoditelji, urednici ili netko treći. ${ }^{36}$ Sa sigurnošću se, međutim, može ustanoviti velika heterogenost kako izabranih djela tako i splitske prevoditeljske grupe. Riječ je, naime, o prevoditeljima i prevoditeljicama različitog obrazovanja i profesionalne orijentacije (književnicima, romanistima, kazališnim djelatnicima, profesionalnim prevoditeljima, publicistima itd.). Dok su se neki od njih na određeni način specijalizirali za jedan žanr (Begović za drame, Nazor

34 Put u Kongo preveli su D. Ivanišević i D. Težak (riječ je o ponovnom izdanju putopisa koji je kod nas prvi put objavljen 1934.), a Krivotvoritelje novca D. Smičiklas. Predgovor romanu napisao je Tin Ujević. Riječ je o Ujevićevom tekstu koji je prethodno objavljen u Republici. V. Tin Ujević, „André Gide“, Eseji, rasprave, članci, sv. 2, Zagreb 1965., 35-45. Valja napomenuti da su između 1952. i 1977. srpski izdavači objavili deset Gideovih djela.

36 U slučaju Gideovog putopisa, izbor teksta kao i izbor predgovarača i izdavača podupiru pretpostavku da je odluka o novom izdanju bila u prvom redu politički motivirana. Ta pretpostavka, međutim, ne isključuje postojanje i nekih dodatnih motiva. Primjerice, Sanja Roić u svom članku o Desnici i Siloneu iznosi stajalište da je riječ o (Desničinom) izboru što je „vjerojatno bio inspiriran Siloneovom antologijom Uscita di sicurezza iz 1949. u koji je bio uvršten upravo taj Gideov prinos“. V. Sanja RoIć, „Dva pisca na meti kritike: Desnica i Silone“, Desničini susreti 2009. Zbornik radova (ur. Drago Roksandić, Magdalena Najbar-Agičić i Ivana Cvijović Javorina), Zagreb 2011., 105. U prilog pretpostavci da se Desnica za Gideov putopis zainteresirao posredstvom Silonea mogla bi se navesti dva podatka: u Desničinoj kućnoj biblioteci nema nijednog Gideovog djela (v. „Popis kućne biblioteke Vladana Desnice“, Hotimično iskustvo. Knjiga druga, 251-279); Desnica je iste godine (1952.) objavio prijevod Siloneovog romana Kruh i vino i Gideovih putopisa, a izdavač je u oba slučaja bio Glas rada. 
za poeziju, Škurla-Ilijić za sentimentalne romane) ili jednog autora (Jurević za Baudelairea), drugi su bili otvoreni za različite autore i (pod)žanrove: poeziju i prozu (Ujević, Cettineo, Alfirević, Rabadan), popularnu i elitnu književnost (Ujević, Tecilazić, Belan, Rabadan), književnost za odrasle i za djecu (Desnica, Belan), književna i neknjiževna djela (B. Begović) itd. Valja ipak istaknuti da u prevoditeljskom opusu pripadnika splitskog kulturnog kruga dominiraju prijevodi značajnih francuskih djela 19. i 20. stoljeća (od realizma do novog romana) i upravo se ti prijevodi mogu držati njihovom najvrjednijom ostavštinom. Zahvaljujući njihovom prevoditeljskom radu, hrvatskim su čitateljima postala dostupna djela klasika francuske književnosti koja čine dio europske i svjetske kulturne baštine.

\section{$\cos$}

\section{Translations of French Literature by Members of the Split Cultural Circle}

The first part of the article deals with translation as an element of intercultural communication, which, in the opinion of French and Croatian comparatists (Van Tieghem, Guyard, Pichois, Rousseau, Chevrel, Masson, Hergešić) and sociologists of literature (Bourdieu, Sapiro, Heilbron), represents important material for literary study and plays an important part in the consecration of both the authors of literary works, the national literature to which they belong, and their translators. Next, the article presents a brief overview of the reception of French literature in Croatia in the closing decades of the $19^{\text {th }}$ century and the opening decades of the $20^{\text {th }}$ century. Special attention is paid to the role played by the members of the Split cultural circle (Milan Begović, Vladimir Nazor, Tin Ujević, Verka Škurla-Ilijić, Ante Cettineo, Božena Begović, Frano Alfirević, Vinko Tecilazić, Bogdan Radica, Jerka Belan, Vojmil Rabadan, Ante Jurević, Vladan Desnica) in the exchanges between French culture and Croatian culture. In doing so, some common characteristics of the group are pointed out: their work was not limited solely to translation; most of them translated from several foreign languages; translated texts belong to diverse genres; the translations were most commonly of French writers of the $19^{\text {th }}$ and $20^{\text {th }}$ centuries; the translations were usually published with Zagreb publishers. The last section of the article deals with Croatian translations of André Gide's travelogue Retour de l'U. R. S. S. (1936), which was published three times in Croatia: in 1937, 1952 and 1980; special attention is paid to the 1952 edition of the Glas rada publishing house, which published the excellent translation by Vladan Desnica.

Key words: literary translation, intercultural communication, comparative literature, Split translators, French literature, André Gide, Vladan Desnica

\section{cos}

\section{Izvori i literatura}

Nikola Andrić, „Našim čitaocima“, u: Paul Bourget, Druga ljubav, Zagreb 1919., 3-5.

Bibliografija rasprava, članaka i književnih radova, sv. I. 3: Nauka o književnosti. Historija stranih književnosti (ur. Ivo Horvat), Zagreb 1959. 
Marijan Bosnar, „Rudi Supek i nacistički koncentracijski logor Buchenwald kroz arhivsko gradivo Hrvatskog državnog arhiva“, Arhivski vjesnik, 54/2011., 153-178.

Pierre Bourdieu, „Les conditions sociales de la circulation internationale des idées“, Actes de la recherche en sciences sociales, 2002., br. 145, 3-8.

Vladan Desnica, „Lađe i galebovi“, Hotimično iskustvo: diskurzivna proza Vladana Desnice. Knjiga prva (prir. Dušan Marinković), Zagreb 2005., 103-105.

Nataša Dragojević - Fikret CACAN, Svjetska književnost u hrvatskim prijevodima 1945-1985. Bibliografija, Zagreb 1988.

Aleksandar Flaker, Riječi slika, grad, rat. Hrvatske intermedijalne studije, Zagreb 2009.

André Gide, Povratak iz S. S. S. R., Zagreb 1937.

André Gide, Povratak iz SSSR; Dopune mom Povratku iz SSSR, Zagreb 1952.

André GIDE, Povratak iz SSSR-a i drugi politički članci, Rijeka 1980.

André Gide, Retour de l'U. R. S. S.; Retouches à mon Retour de l'U. R. S. S., Paris 1978.

Marius-François GuYARD, La littérature comparée, Paris 1965.

Johan Heilbron - Gisèle SAPiro, „La traduction littéraire, un objet sociologique“, Actes de la recherche en sciences sociales, 2002., br. 144, 3-5.

Ivo Hergešić, Komparativna književnost, Zagreb 2005.

Hrvatska enciklopedija, 11 sv., Zagreb 1999. - 2009.

Nenad Ivić, „Rabadanova 'Summula villoniana', Napulj i druga imaginarna mjesta, Zagreb 2009., 114-122.

Jadranska straža (Split), 1927. - 1941.

Zdravka Jelaska Marijan, Grad i ljudi: Split 1918.-1941., Zagreb 2009.

Dražen Katunarić (prir.), Hrvatska/Francuska. Stoljetne povijesne i kulturne veze, Zagreb 1995.

Nevenka Košutić-Brozović, „Francuske književne pobude u časopisima hrvatske moderne“, Rad JAZU, Zagreb 1969., 403-666.

Ivana Mandić Hexman, Zabavna biblioteka. Bibliografija. Katalog, Split - Zagreb 2007.

Dušan Marinković, „Biografija Vladana Desnice“, Hotimično iskustvo: diskurzivna proza Vladana Desnice. Knjiga druga (prir. Dušan Marinković), Zagreb 2006., 217-250.

Claude Martin, Gide, Paris 1963.

Jean-Yves Masson - Yves Chevrel, „Histoire des traductions en langue française“ (http://www. crlc.paris-sorbonne.fr/FR/Page_axe_recherche.php?P1=9).

Cvijeta Pavlović, „Nazorovi prijevodi Baudelairea“, Hrvatsko-francuske književne veze. 15 studija, Zagreb 2008., 145-155.

Claude Pichois - André-Michel Rousseau, Komparativna književnost, Zagreb 1973.

Bogdan RadicA, „André Gide: između vječnog odlaska i povratka“, Agonija Europe. Razgovori $i$ susreti, Zagreb 2006., 127-135.

Sanja RoIć, „Dva pisca na meti kritike: Desnica i Silone“, Desničini susreti 2009. Zbornik radova (ur. Drago Roksandić, Magdalena Najbar-Agičić i Ivana Cvijović Javorina), Zagreb 2011., 101-110.

Drago ŠimundžA, Francuska književnost u „Viencu“, Split 1993.

Tin Ujević, „André Gide“, Eseji, rasprave, članci, sv. 2, Zagreb 1965., 35-45.

Paul Van Tieghem, „Les intermédiaires“, La littérature comparée, Paris 1931., 152-167. 
Maja ZoRICA, „Les pérégrinations de Gide et de Krleža: les Russies ou les lignes de fuite du référent (Retour de l'U.R.S.S., Retouches à mon 'Retour de l'U.R.S.S.' et L'excursion en Russie)“, Les Cahiers ERTA, 2013., br. 3, 143-159.

\section{Internetski portali}

Hrvatski biografski leksikon (http://hbl.lzmk.hr/).

Krležijana (http://krlezijana.lzmk.hr/).

Proleksis enciklopedija (http://proleksis.lzmk.hr/). 